\title{
ENSAIO SOBRE A LIBERDADE DO CRISTÃO SEGUNDO LUTERO
}

\author{
Mathias Möller ${ }^{1}$ \\ “O cristão é um senhor libérrimo sobre tudo, a ninguém sujeito. \\ O cristão é um servo oficiosíssimo de tudo, a todos sujeito."
}

(LUTERO, 1989D, p. 437)

\section{RESUMO}

Este ensaio busca apontar um breve transcorrer histórico-filosófico do medievo no sentido de identificar possíveis contribuições de certos questionamentos da autoridade eclesiástica e da fundamentação da liberdade do indivíduo frente à tirania para o advir das ideias modernas sob a perspectiva individual a partir da afirmação de autonomia do cristão frente à autoridade civil e mesmo eclesiástica, conforme atribuído a Lutero. No entanto, conforme se poderá identificar, a fundamentação da liberdade individual frente à tirania religiosa deve ser seguida com ressalvas. Com efeito, busca-se destacar como essas reflexões sobre os primórdios do Estado laico, certamente mais complexos, podem encontrar na transformação da natureza do poder e nos limiares entre teologia e filosofia, conforme apresenta Chatelêt, respaldo a partir dos escritos políticos do monge agostiniano Martin Luthero.

Palavras chave: Filosofia da Religião / Filosofia Política / Liberdade / Martin Lutero.

\begin{abstract}
This essay is intended to indicate a brief historic-philosophical passage of the Medieval in a way to identify possible contributions of certain questionings of the ecclesiastic authority and of the fundaments of the liberty of the Christian individual for the outcome of modern ideas under the perspective of the individual upon the assertion of the Christian autonomy vis-à-vis the civil and even ecclesiastic authority, as attributed to Luther. Nevertheless, as it can be identified, the fundaments of the individual liberty vis-à-vis the religious tyranny shall be followed with precautions. In effect, it is pointed out how these reflections over the primordial of the laicity of the state, certainly more complex, can encounter in the transformation of the natures of power and in the threshold between philosophy and theology, as presented by Chatelêt, upon the political writings of the Augustinian monk Martin Luther.
\end{abstract}

Key words: Philosophy of Religion / Political Philosophy / Liberty / Martin Luther.

\footnotetext{
${ }^{1}$ Graduando em Filosofia - Unb 


\section{Introdução}

A origem e o destino do poder político são questões respondidas pelo pensamento medieval de forma diversa do atualmente comum. Condenado à adjetivação das trevas pelo pensamento renascentista, a relação mística de justificação das coisas da natureza e do mundo humano como advindas de divindades intocáveis, a era medieval, ainda que muito ampla, pode, no âmbito político, ser caracterizada pela querela da interação entre poder civil e poder espiritual, ou seja, da organização institucional humana, portanto temporal, e divina, portanto espiritual, respectivamente.

O medievo tardio, a esse respeito, é atualmente identificado como anunciador e fundamental para a separação do poder espiritual enquanto autoridade determinante da organização civil, nomeadamente a, à época, Igreja Católica Apostólica Romana. Não obstante, naqueles tempos, essa querela da determinação da autoridade ainda estava claramente pendente para a aqui proposta investigação desde a organização espiritual frente à temporal. A atuação por séculos marcante da Igreja Católica enquanto definidora da autoridade e inquisidora de seus oponentes, em nome do medo das trevas anunciadas, ainda se fazia muito presente na colocação e até imposição da autoridade ou mesmo na simbologia representada na coroação dos monarcas pelo patriarca da Igreja. Contudo, na medida em que a modernidade se anunciava, sua preponderância era decadente.

Os pensamentos alternativos à imposição espiritual para a organização civil laicizada receberam inúmeras contribuições no decorrer dos tempos até a origem do Estado moderno conforme o conhecemos atualmente. Muitas das questões e reflexões a respeito da origem do poder político moderno já receberam inclusive no decorrer dos longos anos de trevas sua fundamentação. Nesse sentido, é instigante notar como um período de obscurecimento da razão e de adesão mística ao poder espiritualmente determinado, sem aqui adentrar as fundamentações religiosas para tanto, em contraposição ao esclarecimento racional, e por isso de luzes, do período subsequente, impõe-se para pensar a possibilidade do abandono das determinações heterônomas religiosas para poder fundar os pensamentos políticos modernos. Instigante identificar enquanto nas trevas é possibilitado o advir e o sobrepor-se do sujeito individual humano para a determinação da autoridade política. A partir das reflexões dos 
teólogos e filósofos medievais, com abordagens e formas de inquirição notadamente diversas, o medievo é cada vez mais estudado enquanto primórdio do pensamento político moderno.

Nesse sentido, objetiva-se com este ensaio apontar um breve transcorrer históricofilosófico do medievo no sentido de identificar possíveis contribuições de certos questionamentos da autoridade eclesiástica e da fundamentação da liberdade do cristão frente a qualquer autoridade que não o próprio Deus para o advir das ideias modernas sob a perspectiva individual a partir da afirmação de autonomia do indivíduo frente à autoridade civil e mesmo do cristão frente à autoridade eclesiástica, conforme atribuído a Lutero. No entanto, conforme se poderá identificar com o objeto específico deste ensaio, a fundamentação da liberdade individual frente à tirania religiosa, tal atribuição a Lutero deve ser seguida com ressalvas. Mas para isso inicia-se com um resgate do pensamento teológicopolítico em operação no tempo de Lutero para então identificar-se a liberdade para o mesmo.

\section{Algumas incursões histórico-filosóficas da relação Estado - Igreja}

Chatelêt resgata o momento histórico da relação entre Estado e Igreja afirmando como que "a partir da conversão de Constantino parece conter a possibilidade de uma solução para esse problema", a institucionalização, a união entre o Imperador, Roma, e o sucessor de São Pedro, o Papa, ainda que o poder militar e administrativo não se funde com a autoridade espiritual do bispo da cidade sagrada, mas Roma se torna o centro da Igreja. Isso remonta, conforme relata Chatelêt, ao ano de 410, quando o rei Alarico, convertido à seita cristã de Ário, saqueia Roma, e Aurelius Augustinus (Santo Agostinho), bispo de Hipona, fora levado a clarificar a questão e sustentar a doutrina da Igreja, escrevendo para tanto Cidade de Deus. A recepção dos escritos de Agostinho e do pensamento neles expressos levam ao que Chatelêt considerou a "inflexão do pensamento cristão" e um marco na cultura europeia (CHATELÊT, 1990, p. 29).

Para os grandes pensadores franciscanos, por exemplo, cuja ordem fora oficialmente declarada instituída pela própria Igreja Católica em 1209, por Inocêncio III, a seu idealizador, Francisco de Assis, a compreensão vigorante de plenitude dos poderes espirituais e temporais 
do Papa começou a ser questionada a fim de poder justificar para a Ordem Franciscana os seus princípios e votos religiosos em exercício no mundo temporal, a saber, o imitatio cristi com o voto de pobreza em contraposição à ostentação de riquezas e avocação de propriedade percebida pela Igreja Católica de sua época. Foi assim, pois, que Guilherme de Ockham deu a voz aos questionamentos ao poder do papa na argumentação a respeito do limite do potestate papae, de qual e até que ponto se daria a autoridade espiritual (OCKHAM, 1988, p. 31). No que, afinal, seria legítimo ao Papa determinar com relação à ordem franciscana no mundo temporal.

Tratar-se-ia, pois, de estabelecer as regras de vida, a conduta dos membros da comunidade cristã, assegurar o triunfo espiritual individual como da própria Igreja. A argumentação para tanto, com efeito, não será aqui desenvolvida, sendo que, conforme resgata Chatelêt, importante é constatar como, diante da institucionalização da religião do Império, as regras cristãs de vida se confluíram com a anterior oposta concepção grecoromana de constituição e manutenção da cidade (dos homens) feliz e virtuosa.

Historicamente, advirá daí longo período em que se confundem filosofia e teologia. Conforme indicado por Chatelêt, viver-se-á os tempos da Patrística, dos "pais da Igreja", cuja determinação dogmática fora de legitimar a instituição eclesiástica, encontrando as condições de definir sua própria legislação interna, o Direito Canônico. Em seu sistema normativo, regula a conduta pessoal dentro da Igreja e também fora dela, institui as formas como esta ordem e a lei divina devem se traduzir para o mundo de fato, exercendo o que Chatelêt apontou ser uma censura rigorosa sobre os costumes em nome de Deus, a origem formal da concepção do Direito e das leis conforme dominam até hoje no Ocidente.

Segundo a concepção agostiniana, desenvolvida na assim conhecida teoria das duas espadas, o poder espiritual (auctoritas) e o poder temporal (potestas) normalizam o Ocidente. De acordo com o indicado por Chatelêt, a separação efetiva entre a ordem temporal, o Império de Roma, e a ordem espiritual, o reinado do Bispo de Roma, o Papa, no século V, argumentava-se a partir das exposições dos Papas Gelásio e Gregório o Grande (540-604). A compreensão era de que somente Deus detém a plenitudo potestatis, a potência suprema. $\mathrm{O}$ mundo, contudo, seria feito de materialidade e espiritualidade, sendo que a delegação onipotente atribuíra a dois poderes distintos o cuidado de fazer a ordem divina triunfar: ao 
Pontífice atribuiu a auctoritas, a mais alta dignidade; ao rei, a potestas; cada qual soberano em seu domínio, o Papa em matéria religiosa e eclesiológica, o Rei sobre seus súditos. Residiria, assim, no desequilíbrio entre ambos a fonte de conflitos (CHATELÊT, 1988, p. 32).

Com Carlos Magno, nos anos 800, e o Sacro Império Romano-Germânico é a comunidade cristã que deve obediência, tendo recebido do pontífice tal segurança. Mais adiante, o Papa Gregório VII humilha o Imperador Henrique IV, nos anos 1077, relata Chatelêt. Com Inocente III e Inocente IV a potestas mais uma vez é conferida ao Papado, assumindo autoridade plena sobre as questões temporais. Nessa época, que antecede os tempos de Guilherme de Ockham, a resistência a Roma receberia inclusive um novo protagonista, os reinados, representantes de comunidades regionais, que iriam contestar o avanço temporal da Igreja de Roma, principalmente com base no direito consuetudinário de origem germânica, afirmando-se diante dos seus súditos como servidores da comunidade, conforme apresenta Chatelêt. Tem-se o início da formação dos poderes nacionais, sobretudo nas regiões que seriam hoje a Inglaterra e a França.

Novo marco nessa relação de poder são as reflexões de Tomás de Aquino, 1225-1274, a partir das quais o pensamento agostiniano declinaria e as comunidades regionais receberiam maior preponderância. Dar-se-ia, então o rompimento com a concepção de que a Cidade dos Homens seria instituída pelo poder divino e regrada em função da decadência do pecado original.

O poder, cada vez mais uma questão humana, servirá para organizar a multiplicidade social a partir da razão, afastando-se da compreensão de desígnio singular de Deus ou de seu representante, ainda que como coletividade participante de ou em respeito ao plano geral da providência divina (CHATELÊT, 1988, p. 33).

As reflexões a esse respeito, quanto aos primórdios do Estado laico, obviamente, são mais complexas que essa breve exposição pode indicar. Nesse mister da transformação da natureza do poder, inclusive, conforme apresenta Chatelêt, presente isoladamente em algumas regiões já em torno do que virá a ser conhecido como direitos da pessoa, importante é destacar como as reflexões e escritos políticos do medievo circunscrevem as ideias do monge agostiniano Martim Lutero. 
A questão em disputa, a esfera de poder do Papa e a cidade dos homens, advém também ainda da obra de Marsílio de Pádua, quando em 1324 publica o Defensor Pacem, que irá definir a tendência geral da separação entre potestas e auctoritas, o Estado laico, para além de sua manifesta intenção de defender as pretensões do poder universal de um imperador alemão e polemizar contra a teocracia romana. Conforme apresenta Chatelêt a questão de Marsílio (CHATELÊT, 1988, p. 35), a defesa da autonomia e da unidade da sociedade política, parte da recusa à autoridade papal, compreendendo que a Igreja é o conjunto de crentes e não poderia ter um chefe; que os padres, responsáveis por preparar os crentes para a salvação, em função da lei, dependam do príncipe assim como todos os demais cidadãos.

Dieter Mertens considera o momento histórico como de disputa sobre soberania, de legitimação filosófica frente à tradição teológica com relação aos limites dos poderes e a estruturação do espaço de ação política (FENSKE et al, 2008, p. 222). Seria a partir de Marsílio de Pádua (c. 1275/1280 a c. 1342) que ocorrera, segundo Mertens, a transição para o que caracterizaram como "soberania do povo", considerando Defensor da Paz como a fundamentação quanto à construção e ao funcionamento do Estado. A posição de Pádua, favorável à supremacia do Estado em relação à Igreja, pode ser percebida quando se posicionou ao lado de Ludwig da Baviera nas divergências com o Papa João XXII.

Marsílio de Pádua, no entanto, ainda estava marcado pela compreensão das altas cidades italianas e não poderia, assim, se basear em igualdades individuais ao propor a construção da sabedoria do povo como o que se encontrará no pensamento político moderno após as ideias de Ockham e Lutero.

Não obstante, Pádua mantém possível o poder imperial, ainda que restrito à lei. Caso o legislator humanus assim legisle, as decisões da Igreja ainda poderiam ser compulsórias para a comunidade política ou vice-versa. Seu objetivo era encontrar uma forma institucional para evitar o exercício injusto do poder imperial, mantendo-o restrito à lei e ao consenso popular. Pádua, portanto, entendia o império, o poder, restrito à lei e ambos restritos ao consenso da coletividade, registra Mertens, mas não previu ações para a ocorrência de uso ilegítimo, abusos do poder, um direito à emergência ou mesmo à revolução, o que fora compreendido por seus críticos contemporâneos ${ }^{2}$, no caso do dilema do poder papal totalitário e da

\footnotetext{
${ }^{2}$ Entre eles Alvarus Pelagius (c. 1275-135), teólogo franciscano.
} 
corrupção pelo uso indevido do poder, como atribuir à esperança franciscana por um Papa puro (FENSKE et al, 2008, p. 224).

De acordo com o sustentado por Mertens, é nesse momento histórico que, a partir de uma argumentação pré-política, que Ockham aparecerá como crítico da Cúria (corte pontifícia) e do próprio Pádua, pois argumentará a partir da fé do cristão como sendo expressão da liberdade individual. Dessa forma, as organizações temporais, mundanas, e espirituais, eclesiásticas, apresentam-se como instituições marcadas pela humanidade. Com efeito, império e Igreja pontifícia adviriam do poder absoluto de Deus (potentia absoluta), tendo sido estabelecidos a partir de inúmeras possibilidades de realização das ordens regulares. Sustentam-se, pois, sob o poder ordinário (potentia ordinata). Seria, então, mais uma vez Deus quem transferira ao Papa a liderança espiritual da Igreja, o qual acreditaria estar, pois, intitulado a agir para além dela, o que, no entanto, seria de mero direito humano, igualmente transferido a ele, por sua vez, pelo crente. A Igreja seria a forma exterior da Igreja invisível (ecclesia universalis) guiada pelo espírito, mas com ela não idêntica. ${ }^{3}$ Assim também não seria o Concílio, mas poderia sê-lo em situação de emergência, quando de um Papa herético (que já o seria ao arrogar a si a plenitudo potestatis). Porém, assim como todos os cristãos, também o Concílio poderia errar, pois contra o erro não ajudaria qualquer instituição humana, e sim apenas a graça. Desse modo, repousaria na obediência da fé do cristão individual, isto é, ao instruído, a quem a fé dominara por meio do entendimento e da vontade, em substituição da ecclesia universalis. Por isso que a liberdade da instrução, da busca pelo conhecimento seria tão importante para a Igreja.

O Concílio de Constance, a partir do Decreto Conciliar de Frequens, de 1417, e as declarações da Conferência de Basileia, alteraram o posicionamento do Concílio frente à Igreja, engendrando até mesmo maiores discussões sobre teorias políticas.

As controvérsias do Concílio de Basileia (1432-1449) são disputas eclesiológicas, mas se mostraram fundamentais para a teoria política, pois se deram em torno de princípios filosóficos. Engendraram reformas na Igreja e no reinado que se deram pelos mesmos fundamentos: o príncipe deveria reformar a Igreja e a Igreja reformar o principado. As

\footnotetext{
${ }^{3} \mathrm{~A}$ impossibilidade de dois corpos distintos serem idênticos remonta à teoria conceitualista, postumamente conhecida por nominalista, sustentada por Ockham em seus textos sobre metafísica (SPADE, 2006. p. 100) . 
discussões, conforme indicadas acima, determinaram as compreensões da época, mas os conciliares, ainda que desenvolveram os argumentos jurídicos e filosóficos predominantes, enfraquecendo os dois lados, não foram exitosos na separação das esferas de poder, pelo que ainda se manteve a compreensão hierárquica desde o poder do Papa por concessão divina, por parte da Igreja, e por concessão constituinte ao príncipe a partir do poder do povo (FENSKE et al, 2008, p. 230).

O período do medievo tardio, nesse sentido, aportou grandes contribuições à arquitetura civil. Com efeito, eis que a confluência de teologia e filosofia já indicava suas cisões, observando-se grandes escritos de ambos os lados das esferas de poder, para além do aqui apresentado.

Dos pensadores políticos, pode-se destacar aqui, quanto às reformas do principado, exemplos do pensamento humanista italiano, com as teorias de utopia, de Thomas Morus (1478-1535), e de razão de Estado, de Maquiavel (1469-1527).

Do lado dos pensadores destacadamente religiosos, muitos dos quais mais empenhados na reforma das estruturas eclesiásticas de poder, engendraram-se importantes reflexões com relação ao pensamento político. Contudo, nesse período, os reformadores da Igreja, conforme posteriormente conhecidos, expunham suas fundamentações a partir da compreensão principalmente teológica mais que filosófica, e assim devem ser compreendidos.

Conforme destaca Eugenio Ímaz na abertura de sua tradução à obra de Ernst Troeltsch, pontos supostamente conquistados pela modernidade têm na reforma protestante seus antecedentes, como o livre arbítrio, a salvação por fé, o sacerdócio universal, o direito à rebelião, a democracia paroquial, a legitimidade da cobrança de interesses e outros (TROELTSCH, 1951, p. 8). Troeltsch chega a afirmar que, se considerarmos a conexão mais imediata, a cultura moderna surgiu da época da cultura eclesiástica (TROELTSCH, 1951, p. 14).

Uma das questões determinantes para o pensamento moderno destacadas por Troeltsch, e importantes para o ensaio aqui desenvolvido, é o domínio da autonomia frente à autoridade, engendrada a partir de uma legitimidade desde o indivíduo, que se funda em convicção puramente autônoma e racional. Autonomia esta, segundo sustenta, que traria consequências imediatas enquanto individualismo na formação de convicções, teorias e fins 
práticos próprios. A infalibilidade divina dando lugar para a relatividade humana de normatização objetiva convencionada a partir da arbitrariedade subjetiva do indivíduo; a revelação substituída pela ciência como autoridade (TROELTSCH, 1951, p. 17-18). Pontos que, desde a derrubada da autoridade, levariam à possibilidade de um princípio autônomo gerador de verdade e de ética, assim como levariam à intransponível cadência da corrupção originária do ser humano desde o pecado original (TROELTSCH, 1951, p. 19).

\section{Livre e servo - a liberdade do cristão com Lutero}

Não obstante essa indicação de secularização, afirmada por Troeltsch, os posicionamentos à época, conforme indica Wolfgang Reinhard, mesmo nos reformadores da Igreja, se encontram mesclados entre teologia e filosofia. Muitas vezes são mesmo dependentes das situações que ensejaram a argumentação dos teólogos, como as predominâncias democrática, nos pensamentos de João Calvino, e autoritária, nos de Lutero. Este, por vezes até afirma seu movimento reformador a partir da situação política, e até chega a sustentar seu pensamento político a partir da compreensão teológica, destaca Reinhard. Desse modo, na compreensão de Lutero diante da situação sócio-política em vigor em sua época, seja pela corrupção na Igreja ou na sociedade, são os fundamentos evangélicos que poderiam e até mesmo deveriam reformar a ambos (FENSKE et al, 2008, p. 268).

Segundo resgatam Reinhard, Lutero não se pronunciou sistematicamente quanto à política e nem mesmo quanto à teologia. Seus textos são centrados em casos problemáticos que resolve por meio de seus axiomas fundamentais. Soluções práticas a partir das quais apresentará recomendações práticas para a vida (FENSKE et al, 2008, p. 268).

Lutero, a esse respeito, pela concepção que estabelece entre indivíduo externo e interno, impôs uma distinção da individualidade, sendo que ao interno são os dez mandamentos que ensinam "como a pessoa deve portar-se frente a Deus interiormente" (LUTERO, 1989B, p. 175). Devido ao cunho mais político daquele frente ao mais teológico deste, o primeiro é que recebe neste ensaio maior ênfase, ainda que seja determinado pela teologia, portanto pelo indivíduo interno. 
Ao posicionar a Reforma como "primeira grande revolução dos tempos modernos", Luis Alberto de Boni cita Hegel na introdução de sua organização de textos da reforma protestante para apresentar a liberdade como uma realização interior decorrente da relativização da autoridade eclesiástica, de modo que "o espírito subjetivo torna-se livre (...) esse é o conteúdo essencial da Reforma: o homem é determinado por si mesmo para ser livre" (BONI, 2000, p. 11-12).

Assim, pode-se compreender essa liberdade do cristão, a que De Boni destaca não se reduzir à sua mera interioridade, mas que cria um mundo diferente, o mundo da sociedade (BONI, 2000, p. 13). É, pois, como, a partir do questionamento da autoridade religiosa, se forma essa liberdade interior enquanto indivíduo cristão posto no mundo exterior, a questão central deste ensaio. É o que De Boni anunciou como moralidade cristã: como orientar a própria vida em sociedade seguindo os princípios cristãos.

As reflexões a esse respeito podem ser norteadas pelo debate com um dos, talvez o principal texto de cunho mais político de Lutero: Sobre a liberdade cristã, tendo, conforme exposto por De Boni, a chave de compreensão de seu pensamento ético-político na visão de ser humano de Lutero, ou seja, aquele salvo, portanto livre pela fé e chamado à fé pela palavra de Deus, portanto servo (BONI, 2000, p. 21). A doutrina dos dois reinos (de Deus e dos homens) dos quais o cristão participa enquanto humano como seu principal fundamento (LUTERO, 1996A, p. 84), ainda que para De Boni tal doutrina estaria sujeita a diversas interpretações e objeções. Desde sua fundamentação por Agostinho, tal compreensão permeia as idéias políticas sustentadas pelos pensadores católicos, tônica aparentemente inevitável deste ensaio, da qual o monge agostiniano Lutero não se diferencia. Afinal, é a partir desse dualismo de mundos que se pode entender mais plenamente afirmações clássicas de Lutero como: orat et laborat; ou mesmo: livre e a ninguém sujeito e servo a todos sujeito.

De Boni destaca ainda, tecendo analogias ao apóstolo Paulo, que as exposições teóricas de Lutero não costumavam acompanhar os enunciados práticos, pelo que se cria uma tensão entre teoria e prática, dogma e ética. Ademais, aponta De Boni, Lutero se apresenta como um conservador em questões políticas de sua época, ainda que tenha ensejado a revolução posterior com seus escritos e discursos (BONI, 2000, p. 22). 
O ano de 1520 foi particularmente importante no que tange à produção intelectual de Lutero. Ano em que manifestou sua preocupação e necessidade de reforma tanto da liderança quanto dos membros da Igreja em À nobreza cristã da nação alemã. Neste texto, defenderá a igualdade de todos os cristãos pela comunidade de fé, o sacerdócio universal, diferindo o sacerdote do fiel apenas por desempenho de ofício. A partir do batismo e da fé, portanto, seguindo a metáfora paulina do corpo em unidades e igualdade dos cristãos (1 Co 12,12), Lutero sustenta que as pessoas se tornariam cristãs, pessoas espirituais, e assim partícipes do reino de Deus de modo que: "todos os cristãos são verdadeiramente de estamento espiritual, e não há qualquer diferença entre eles a não ser exclusivamente por força do ofício" (LUTERO, 1989A, p. 282). Uma comunidade de fé em que não haveria hierarquia estrutural, nem poderia um membro arrogar a si acesso privilegiado à palavra de Deus, pelo que Lutero se empenhará a permitir a leitura não mediada da Bíblia, traduzindo-a para o vernáculo.

Nesse mesmo ano de 1520, Lutero apresenta a obra em que, em uma espécie de tratado, discorre Sobre a liberdade do cristão. Para tanto, se embasará em duas afirmações bíblicas para sustentar sua tese de liberdade espiritual, interior, e servidão corporal, exterior.

De Boni pontua a importância da relação entre as duas esferas, entendendo que para Lutero elas não se tocariam, já que nada do exterior tornaria o ser humano justo. Apenas o interior do cristão o torna livre pela fé (BONI, 2000, p. 25), em oposição à concepção presente à época de que as ações da esfera externa possibilitariam influenciar ou mesmo determinar a esfera interna da pessoa e até mesmo de outras pessoas já não mais presentes no mundo exterior, ou seja, as indulgências. Lutero empreenderá uma de suas principais críticas à Igreja de seu tempo sustentando-a no estado de cativeiro babilônico frente à liberdade do cristão, de que a pessoa cristã não viveria em si mesma, mas em Cristo, pela fé, e em seu próximo, pelo amor (LUTERO, 1989D, p. 456).

A partir disso, em seu texto Da autoridade secular, de 1523, Lutero irá estabelecer o que compreende por legítimo à autoridade temporal fazer, a saber, fundamentalmente não interferir ou denegrir a liberdade espiritual do cidadão. Conforme destaca Martin Dreher, o texto fora justamente escrito a partir de sermões proferidos em Weimar, em 1522, a pedido do Duque João Frederico da Saxônia, a quem adiantara folhas avulsas enquanto, em exílio no castelo de Wartburg, procedera com a tradução do Novo Testamento, e como resposta a seu 
irmão, Jorge da Saxônia, o governante que, em 7 de novembro de 1522, havia proibido a compra e a venda da edição de sua tradução (LUTERO, 1996A, p. 79).

De Boni ressalta a esse respeito que o reino de Deus seria onde o ser humano se tornaria justo diante de Deus; já o reino do mundo, por sua vez se destinaria a manter a paz exterior, possibilitando a convivência dos homens. O limite do reino do mundo estaria em imiscuir-se em assuntos de consciência de fé, quando o cristão deveria apelar para a resistência pacífica, pelo que Lutero revoluciona a concepção agostiniana, definindo limites ao poder secular quanto à afirmação religiosa, de foro estritamente íntimo da pessoa, e onde o poder público não poderia interferir (BONI, 2000, p 26).

Martin Dreher, em nota introdutória ao texto de Lutero na edição organizada por De Boni, situa Sobre a liberdade cristã, de outubro de 1520, como texto livre de tentações, antônimo a Do cativeiro babilonico, (BONI, 2000, p. 45), , no qual Lutero enfatiza como a Igreja estava privada de sua liberdade ao ser mantida cativa pelas autoridades eclesiásticas como no antigo Egito, as quais impunham sacramentos que na compreensão de Lutero não se fundamentavam na leitura bíblica, mas sim na tirania das autoridades religiosas com fulcro dominador por um império terreno preso às paixões do corpo, aumentando severamente sua crítica pronunciada quando expôs as Explicações do debate sobre o valor das indulgências (LUTERO, 1996A, p.79).

A exposição em nota de Martin Dreher pode ser tomada como um resumo da obra e até mesmo da ética cristã segundo Lutero. O centro é a tese paradoxal da liberdade sobre todas as coisas e a servidão para com todos os homens. Para Dreher isso se dá em torno da compreensão de que a pessoa interior livre é idêntica à justificada, ela não pode ser presa nem liberta pelo mundo exterior. O caminho para a justificação se daria unicamente pelo Evangelho de Jesus Cristo, pelo que Lutero engendrou a revolução do pensamento teológico enfatizando a mensagem evangelística, a libertação por graça e fé, conforme ele compreendia estar resgatando a mensagem da Igreja primitiva. Por isso uma reforma da e na Igreja e não uma cisão. Seria, pois, sustenta Dreher, a mensagem, a palavra do Filho de Deus, que só poderia ser recebida pela fé, sendo ela, assim, a única justificação, e não alguma obra do ou no mundo exterior. Com efeito, conforme Cristo se relacionou incondicionalmente com todo 
ser humano, fazendo dos crentes reis e sacerdotes, não haveria diferenças entre sacerdotes e leigos, eliminando-se o cativeiro eclesiástico de dominação (BONI, 2000, p. 45-46).

A segunda parte da tese paradoxal, conforme destacada por Dreher, é a servidão do cristão. Diz respeito à natureza externa da pessoa. Sendo assim, essa liberdade do crente não é libertinismo, pois enquanto terreno necessita do controle do próprio corpo. Além disso, ela diz respeito ao relacionamento com o próximo, pelo que o cristão segue o exemplo de Cristo e serve em liberdade, tornando-se um Cristo para o próximo e vivendo assim em comunhão com Deus, o amor como resultado da fé e que tornaria o cristão servo de todos. Contudo, o tratado da liberdade cristã, ressalta Dreher, trata de uma liberdade que resulta da justificação e é dirigida à autoridade legalista eclesiástica. Com significado emancipatório, se volta contra uma igreja repressora e tem consequências para um engajamento humano em prol da salvação também para o próximo (LUTERO, 1996D, p. 46).

Desse modo, pode-se entender a ação civil do cristão com caráter evangelizador. Por ser liberto pela fé busca libertar também ao seu próximo a partir da mesma fé. O que, porém não poderá ser aqui desenvolvido com o devido cuidado.

Conforme Lutero propriamente o apresenta, a pessoa humana tem uma natureza dupla, a espiritual e a corporal (LUTERO, 1996D, p. 47). A natureza espiritual, indica Lutero, corresponde ao que àquele tempo era denominado de alma, para ele, ademais, a pessoa interior é a pessoa nova, ou seja, a renovada, justificada pela fé, segundo sua compreensão teológica. Já a exterior, de natureza corporal, era o que se denominava carne, a pessoa velha, carnal e exterior. É, pois, a pessoa interior a que se destinam as investigações de Lutero, essa individualidade não carnal do ser humano que o permite se tornar uma pessoa justa ou "livre e verdadeiramente cristã" (LUTERO, 1996D, p. 47).

Desse modo, com o texto: Sobre a liberdade cristã (que sob a ótica ora analisada poderia estar respondendo à pergunta: a quem está sujeito o indivíduo cristão), Lutero expõe a fundamentação para sua dupla tese: 1) O cristão é um senhor libérrimo sobre tudo, a ninguém sujeito. 2) O cristão é um servo oficiosíssimo de tudo, a todos sujeito (LUTERO, 1996B, p. 437).

Centrando-se a análise nestas teses aparentemente paradoxais, pode-se compreender a proposta ético-política contida no texto e talvez mesmo na obra de Lutero. Segundo ele, há 
concordância entre as duas teses, as quais extraiu da carta de Paulo à comunidade de Corinto, quando afirmou: "Embora livre, fiz-me escravo de todos" (1 Cor 9,19), e na carta aos romanos: "A ninguém fiqueis devendo qualquer coisa exceto que vos ameis uns aos outros" (Rm 13,8). Ambas as cartas estão em referência a Jesus Cristo, o qual, enquanto Deus se fez humano e servo de todos ${ }^{4}$.

Após o anúncio de suas referências bíblicas, Lutero indicará como a primeira tese se dirige à pessoa interior, de natureza espiritual, à alma, e como a segunda, à pessoa exterior, de natureza física, ao corpo, seguindo ainda a divisão referida por Paulo em sua carta aos coríntos.

A pessoa humana, o indivíduo, é, portanto, formado por espírito e carne. O espírito, contudo, é passível de libertação, não havendo em absoluto nenhuma coisa externa, i.e. do corpo, que tenha significado para a aquisição da liberdade cristã e, com isso, tampouco o tem para a aquisição da servidão (BONI, 2000, p. 47). Nenhuma coisa externa "alcança a alma para libertar ou escravizá-la", não há obra que possa "ser feita por meio do corpo (...) para [trazer] justiça e liberdade à alma. (...) A alma pode carecer de todas as coisas exceto da palavra de Deus. (...) tendo a Palavra, ela é rica, de nada mais carecendo" (BONI, 2000, p. $48)$.

Com isso, a salvação da alma está ligada à palavra, à linguagem, pronunciadamente humana. Porém, a toda e somente àquela palavra que provém de Deus, tendo sido Cristo, os apóstolos e toda ordem clerical chamados e instituídos por Deus para o "ministério da Palavra" (BONI, 2000, p. 49). Notadamente, Lutero reconhece que a comunicação entre corpo e alma, ainda que não assim por ele tratada, é o ponto metafísico em questão, indagando-se, logo em seguida, sobre o que seria esta palavra.

Mais uma vez será Paulo sua referência textual, segundo a carta aos romanos, pela qual a Palavra é o evangelho de Deus a respeito de Jesus Cristo. Ela não pode ser recebida nem cultivada por obras do corpo, mas tão somente pela fé. Se de todo coração confessar-se a pessoa a Jesus Cristo, tornar-se-á uma nova pessoa por meio da fé. São as obras de Deus por meio de Cristo que concedem o perdão a todos os pecados humanos. Os méritos são todos de Deus.

\footnotetext{
${ }^{4}$ Vide registros em Gl 4,4 e Fl 2,6s, citados por Lutero.
} 
Diante dessa promessa, que vem de Deus, Lutero irá assinalar uma divisão da escritura de Deus em preceitos e promessas. O Antigo Testamento, imbuído de leis que mostram o que se deve fazer, são os preceitos necessários para a salvação na medida em que "são ordenados, porém para revelar a pessoa a si mesma para que assim reconheça sua impotência para o bem e desespere de suas próprias forças. (...) [pois] todos ele são igualmente impossíveis" (BONI, 2000, p. 51). Assim, aquele que aprendeu sua impotência diante dos preceitos necessários à salvação, que humilhado diante de sua incapacidade de por seus próprios meios alcançar a salvação, este encontrará no Novo Testamento as promissões de Deus, que anunciam a liberdade para todo aquele que crer. O que é impossível em todas as obras da lei será cumprido pela fé. As promessas de Deus dão de presente o que os preceitos exigem, e cumprem o que a lei ordena, para que tudo seja exclusivamente de Deus (...). Só ele dá preceitos, só Ele os cumpre” (BONI, 2000, p. 51).

Com efeito, Lutero causou inquietação nos detentores do poder clerical de sua época, pois apresentava uma compreensão da palavra de Deus centrada na graça, restando necessário à pessoa cristã apenas a fé, não mais obras para ser justificada: "Se não precisa de obras, também não precisa da lei; se não precisa da lei, é certo que está livre da lei, (...). Esta é a liberdade cristã, nossa fé” (BONI, 2000, p. 52).

Isto posto, a primeira tese é sustentada, pois elevado acima de todas as coisas por meio da fé, o cristão se torna claramente senhor de tudo pelo poder espiritual, de tal forma que nada lhe pode causar dano algum (BONI, 2000, p. 57). Porém, conforme Lutero cita Cristo segundo $1 \mathrm{Pd} 2,9$, todo cristão é rei e sacerdote, pelo que introduz a segunda parte da tese paradoxal sustentada (LUTERO, 1996B, p.444).

O cristão não é apenas rei livre. Assim como com Cristo é salvo, com Cristo é sacerdote. Quem não crê é servo de tudo e faz uso das coisas para seu próprio proveito, não para a glória de Deus. Como co-sacerdotes, afirmará Lutero, não há nas escrituras nenhuma diferença entre sacerdotes e leigos na Igreja, todos são servos de Deus para com os outros, como ministros da Palavra que ensinam a fé em Cristo e a liberdade dos fiéis, a diferença entre papas, ministros e leigos é o ensino público da Palavra.

Seguramente, as palavras de Lutero neste aspecto foram de revolução da ordem estabelecida, pois ele sustentava que leigos e clericais tinham o mesmo status de cristãos. Seu 
ataque, por assim dizer, foi à tirania exercida pela Igreja de sua época, que considerou estar "num cativeiro babilônico", conforme em sua obra homônima, pois transformara em perversidade o que deveria ser ensinamento da graça, substituíra a "liberdade cristã e de todo o Cristo (...) por obras e lei humanas num cativeiro intolerável." Contudo, pelo exposto, podese perceber como essas ideias decorreram de sua leitura e compreensão da Palavra, o que buscou reestabelecer na Igreja da época, refundar a Igreja foi seu intento declarado; reformála.

É à pessoa exterior que se dirige a segunda parte da tese. Por causa dela existem as boas obras, pois perfeitamente interior, espiritual, será o cristão apenas com a ressurreição dos mortos, na vida após a morte. Até lá, viverá na carne mortal, no mundo, na “cidade dos homens". Nela o cristão é servo de tudo e a todos sujeito. Enquanto parte mortal sobre a terra, deverá governar seu próprio corpo e lidar com pessoas. "Aqui e agora começam as obras; (...) há que se cuidar para que o corpo seja exercitado com jejuns, vigílias, trabalhos e outras disciplinas moderadas, e seja subordinado ao Espírito, para que obedeça e seja conforme à pessoa interior e à fé" (BONI, 2000, p. 61).

Desse modo, afirma Lutero, a pessoa interior é criada à imagem de Deus pela fé e se alegra por causa de Cristo seu salvador, "razão por que tem uma só preocupação: servir a Deus com alegria e gratuitamente, em livre amor." A pessoa exterior, em sua carne, tem "uma vontade contrária, que se esforça por servir ao mundo e buscar o que é seu." Por isso, seu corpo, que a pessoa não pode ficar ociosa, mas é obrigada a obrar coisas boas e submeter o corpo à servidão. Dar valor à obra, para Lutero, assim, é dar valor à mortificação do corpo, o qual não pode agir na alma, nem para o bem, nem para o mal, conforme dirá a seguir: "nenhuma obra má faz dele uma pessoa má ou a condena, e sim a incredulidade. (...) pecado é afastar-se de Deus, isto é, não crer” (BONI, 2000, p. 64). Portanto, boa será a obra feita na fé e má aquela feita na incredulidade.

Ora, mas enfim porque tornar-se servo na carne? A resposta Lutero igualmente encontra em Cristo. A partir dele, que enquanto Deus se fez servo para salvar o crédulo, deverá o cristão ser com Cristo também servo de todos, obediente até a morte, segundo citou a carta de Paulo aos Filipenses. Abundando de todos os bens, ou seja, não necessitando de nenhum, nem de obras para se salvar, "não se ensoberbeceu com isso (...), agiu, operou, 
sofreu, morreu (...) ficou semelhante às demais pessoas. (...) fez tudo (...) para nos servir e para que se tornasse nosso tudo o que Ele realizou nesta forma de servo" (BONI, 2000, p. 69). De igual modo deverá a pessoa servir, pois reconhecendo as preciosas coisas a ela dadas nela se difundirá, por meio do Espírito, o amor que a tornará obradora livre, serva dos próximos e senhora sobre tudo. Tal qual lhe foi auxiliado gratuitamente em Cristo, auxiliará ao próximo gratuitamente pelas obras, e tornar-se-á como que um Cristo para o outro, para ser uma verdadeira pessoa cristã (BONI, 2000, p. 70). Isso não para conquistar para si qualquer vantagem, temporal ou eterna, e sim livre e gratuitamente, sendo de fato pessoa boa e cristã (BONI, 2000, p. 73). Viverá não em si mesma, mas em Cristo, pela fé, e no próximo, pelo amor (BONI, 2000, p. 74).

Não ficará, o cristão, pela fé em Cristo livre da obra, mas do falso conceito das obras, de que elas possam justificá-lo. Enquanto corpos mortais, "nos encontramos no mundo coagidos pela necessidade da vida deste corpo, mas por isso não somos justos”, dirá Lutero seguindo a afirmação de Cristo (Jo 18,36) de que Seu reino não seria deste mundo, e a afirmação de Paulo aos coríntos de que ainda que andemos na carne não militamos segundo ela (2Cor 10,3) (cit?).

Para Lutero, o fato de não sermos justificados pelo corpo deste mundo não permite entender as afirmações de Cristo e de Paulo como uma negação de que o reino de Deus não esteja neste mundo (BONI, 2000, p. 76). Por isso a necessidade do governo da pessoa exterior e da fé para a interior.

Assim como Lutero enquanto membro da ordem eclesiástica procurou por dentro da estrutura propor a reforma da igreja universal a partir do resgate da leitura da Palavra por meio da graça, da liberdade cristã, Lutero encontra contemporaneamente uma proposta de leitura também feita por dentro da estrutura eclesiástica. Como um dos principais pensadores luteranos no Brasil, e que posteriormente a seus escritos primordiais assumiu a Presidência da Igreja Evangélica de Confissão Luterana no Brasil, Walter Altmann indicou uma leitura da liberdade do cristão a partir da teologia da libertação, conforme sugere em seu livro Lutero e libertação (ALTMANN, 1994).

Conforme exposto por Altmann, a liberdade do cristão se dá enquanto partícipe dos dois reinos, Igreja e Estado, sendo que as ideias de Lutero permitem ao menos três 
interpretações possíveis e assim observadas nas principais correntes protestantes atuais, a saber: i) a da "demonização do político", em sua primeira variante, a qual afirma ser a esfera do político a característica do mundo caído no pecado, o que seria uma tendência do movimento mais pentecostal e que, a partir disso, permitiria a compreensão de uma antipoliticidade do cristão que busca refúgio na ordem espiritual. ii) A segunda variante seria a "autonomia do político", ou seja, que as esferas são claramente separadas e não devem interferir uma na outra, o que, por sua vez, permitiria a compreensão de que o cristão se posicionaria por um lado indiferente ao político, mas por outro também entendendo o Estado como sendo parte da criação de Deus, portanto, determinado por Deus e em princípio bom. iii) A terceira variante, enfim, a liberdade do cristão, que, a propósito, é a sustentada por Altmann como a mais adequada às ideias de Lutero, ainda que sob a ótica da teologia da libertação, pois, ao contrário das duas primeiras, é a única que não permite subversões à manutenção do status quo, sendo, portanto, reformadora, mesmo revolucionária.

Essa terceira interpretação posiciona a Igreja em aliança com o Estado. Assim como a segunda, ela divide as competências de atuação (auctoritas e potestas), mas se distingue dela ao passo que a separação se dá em "cooperação ativa". A aliança atribui uma tarefa independente e específica a cada esfera, mas estabelece que ambas se fundam a partir e em favor do povo e não dos interesses dominantes, ou seja, "em favor da implantação do reino de Deus. (...) do novo céu e da nova terra". Tanto a "Igreja quanto o Estado, como ainda o próprio ser humano, devem ser colocados no marco fundamental da luta de Deus contra os ídolos [o mal]" (ALTMANN, 1994, p. 162-167).

\section{Ensaiando conclusões}

Com efeito, verifica-se uma representação da postura política decorrente da compreensão teológica, ainda que não tenha sido possível aqui explicitar devidamente o fundamento teológico, pode-se compreender como se traduz a teologia de Lutero em práxis política. Não obstante, apesar de Troeltsch propriamente indicar que o pensamento político do pensamento protestante original deve e pode apenas ser concebido e compreendido a partir da fundamentação teológica, pode-se perceber que ela de certo modo escapou à sua leitura, assim 
como percebido em algumas doutrinações posteriores e não apenas por Troeltsch, conforme apresentado por Altmann. Ora, mesmo o luteranismo mais contemporâneo apresenta dificuldades na correspondência entre o sentido original operado pela reforma com Lutero, o que indica ser preciso ater-se com mais cuidado à exposição do protestantismo. Tal dificuldade, inclusive, já se encontra expressa no texto de Lutero sobre o cativeiro, pelo qual especificamente se dirigiu em crítica ao posicionamento da Igreja de sua época, que operava as indulgências como possibilidade de por ato aquisitivo poder libertar outra pessoa. Atitude essa decorrente da equivocada compreensão de que a fé se daria enquanto uma operação humana, pessoal e voluntária, ao contrário do que entendia Lutero, para quem a fé seria obra divina, independente da opção do ser humano em ter fé de um momento em diante, ou mesmo de impor a fé a outro, e muito menos de ter fé por outro.

Preservar o espírito reformador buscado por Lutero seria, pois, resgatar aquilo que permite encontrar a nova Igreja, a Igreja como instrumento de comunhão e libertação espiritual, e o novo Estado, aquele promotor e defensor de uma sociedade participativa (de e para o povo), igualitária e em função do bem comum (ALTMANN, 1994, p. 167-196).

Preservar-se-ia, assim, o mesmo princípio que levou Lutero a questionar a venda de indulgências, o cativeiro babilônico, de que não há algo que a natureza corporal possa fazer para justificar a alma, nem que a luta pelo reino terreno faça perder o paraíso. A pessoa interior de Lutero vista não como alma de todo ser humano, mas do cristão justificado; um conceito de certo modo ideal da pessoa justificada. Compreender, pois, a liberdade cristã em Lutero como uma mera conviç̧ão pessoal e certeza da salvação eterna se mostraria uma simplificação descabida e abdicação da graça por ele resgatada e novamente fundamentada.

Contudo, mesmo que "o protestantismo quebrou a força da cultura eclesiástica, apesar de sua reanimação passageira [com a contrareforma], mediante a ruptura do domínio único da Igreja católica" (TROELTSCH, 1951, p. 52), permanece a ser esclarecida a operação da conversão, ou seja, da ação humana de perseverar na promessa da salvação, da libertação, segundo Lutero, pois, a partir do batismo se recebe a promessa de Deus, mas a fé não é obra que possa ser feita pelo indivíduo.

Para tanto, a sequência de trechos a respeito do sacramento do batismo e outras referências de Do cativeiro babilônico da Igreja, texto mais teológico e com certas 
referências políticas, podem apresentar o que indico aqui faltar ou ter sido incompreendido na percepção moderna de que no protestantismo estaria o princípio da possibilidade autolibertária de conversão do indivíduo em base fundamental do edifício moderno, que a partir de uma convicção pessoal e excluindo-se Deus dessa: "metafísica religiosa da liberdade e da convicção pessoal da fé (...) que nada 'demasiado humano' pudesse corrompê-la" (TROELTSCH, 1951, p. 108). Cito Lutero:

\begin{abstract}
"Batismo é a promessa divina, (...) 'Quem crer e for batizado será salvo' (...) a fé, contudo, não é obra, mas a mestre e vida das obras. (...) Uma vez que se nos tenha promulgado essa promessa divina, sua verdade persevera até a morte. (...) a não ser que se negue a crer [pois se] permanece firme sua fé na promessa divina que lhe foi feita quando foi batizada, todos os demais pecados são instantaneamente absorvidos pela mesma fé, ou melhor, pela verdade de Deus (...) não deves ter a fé por algo vil, pois é a obra mais excelente e mais difícil de todas. Somente por ela te salvarás (...). Ela é obra de Deus e não do ser humano, como ensina Paulo. As demais ele realiza conosco e por nós, mas esta única é efetuada em nós e sem nós." (LUTERO, 1996C, p. 376-379, com grifo próprio).
\end{abstract}

Diante disso, torna-se inconsistente pensar, a partir de Lutero, que um indivíduo possa se tornar cristão por ação própria, marcando de um momento para o outro, como em ações de re-batismo em adultos, por exemplo, a opção de conversão a Cristo após a deliberação de ter fé. Por conseguinte, não facultará ao indivíduo ser um justificado, portanto, por si só ser livre de todas as coisas.

\title{
REFERÊNCIAS
}

ALTMANN, Walter. Lutero e libertação. São Paulo, Ática: 1994.

BONI, Luis Alberto de. O não-poder do papa em Guilherme de Ockham. Veritas, Porto Alegre, v. 51, n. 3, p. 113-128, set 2006.

. (Org.). Escritos seletos de Martinho Lutero, Tomás Müntzer e João Calvino. Petrópolis, Vozes: 2000.

. (Org.). Idade Média: Ética e Política. 2. Ed. Porto Alegre: Edipucrs, 1996.

CHATELÊT, François; PISIER, Evelyne; DUHAMEL, Olivier. História das Ideias Politicas. 2. Ed. Rio de Janeiro: Zahar, 1990.

FENSKE, Hans; MERTENS, Dieter; REINHARD, Wolfgang e ROSEN, Klaus. Geschichte der politischen Ideen. 3. ed. Frankfurt: Fischer Taschenbuch Verlag, 2008. 
LUTERO, Martin. À Nobreza Cristã da Nação Alemã, acerca da Melhoria do Estamento Cristão. In: Obras selecionadas. Volume 2. São Leopoldo/Porto Alegre, Sinodal/Concórdia, 1989. p. 277-340.

. Breve Forma dos Dez Mandamentos. Breve Forma do Credo. Breve Forma do Pai-Nosso. In: Obras selecionadas. Volume 2. São Leopoldo/Porto Alegre, Sinodal/Concórdia, 1989. p. 171-195.

Do cativeiro Babilônico da Igreja. In: Obras selecionadas. Volume 2. São Leopoldo/Porto Alegre, Sinodal/Concórdia, 1989. p. 341-424.

- Tratado de Martinho Lutero sobre a Liberdade Cristã. In: Obras selecionadas. Volume 2. São Leopoldo/Porto Alegre, Sinodal/Concórdia, 1989. p. 435-460. Da autoridade secular, até que ponto se lhe deve obediência. In: Obras selecionadas. Volume 6. São Leopoldo/Porto Alegre, Sinodal/Concórdia, 1996. p. 79-114. Da Guerra contra os Turcos. In: Obras selecionadas. Volume 6. São Leopoldo/Porto Alegre, Sinodal/Concórdia, 1996. p. 410-465.

Do Cativeiro Babilônico da Igreja: Obras selecionadas. Volume 6. São Leopoldo/Porto Alegre, Sinodal/Concórdia, 1996. p. 341-424.

. Magnificat, traduzido e explicado. In: Obras selecionadas. Volume 6. São Leopoldo/Porto Alegre, Sinodal/Concórdia, 1996. p. 20-78.

OCKHAM, Guilherme de. Brevilóquio sobre o principado tirânico. Petrópolis: Vozes, 1988.

SPADE, Paul Vincent. Ockham's Nominalist Metaphysics: Some main Themes. In: Cambridge Companion to Ockham. Cambridge: University Press, 2006. p. 100-117.

TROELTSCH, Ernst. El Protestantismo y el mundo moderno. Trad. Por Eugenio Ímaz. México, D.F.: 1951. 